\title{
WHERE HAVE ALL THE REVOLUTIONARIES GONE? HUMAN RIGHTS AND THE REINVENTION OF REVOLUTION IN REBIYA KADEER'S DRAGON FIGHTER
}

By Katharine Lu

For five and half years, Rebiya Kadeer was imprisoned as a political prisoner in China and was finally released in 2005 after Amnesty International campaigned for her release. Today, she now campaigns as a human rights activist against what many Uyghurs consider Chinese occupation of their homeland, Xinjiang. Although many organizations work on human rights violations against the Uyghurs, Rebiya Kadeer has emerged as the primary symbol of Uyghur resistance in China, much like the Dalai Lama for Tibet.

Her simultaneous position as both a human rights activist and resistance symbol offers a unique vantage point in exploring the relationship between memory, women, and nationalism. In sketching out these connections, this paper will analyze the agency and representation in the process of memory making and the gendering of resistance in relation to the life and memoir of Rebiya Kadeer. The political project of witnessing through representation offers a practical departure point for better understanding the formation of a feminine revolutionary subjectivity in contrast to the romanticized icon of the masculine, revolutionary hero. In proposing the relationship between memory, women and nationalism, this paper aims to ultimately understand whether the revolutionary subject has in effect become the human rights activist. And if this is the case, what then are the conditions for revolution, and is revolution possible within the logic of human rights discourse?

\section{Contextualizing Uyghur Discontent}


Uyghur discontent today can be attributed to the steady accretion of discriminatory social and economic policies since 1949. According to an Amnesty International Report, Uyghurs face intense pressure to assimilate linguistically and culturally to Han Chinese practices. The implementation of the One Child policy, which allowed Uyghurs two children because of their status as a minority, angered many Uyghurs. The limitations on childbirth were interpreted as a brazen attempt to stunt the Uyghur population, which some understood as genocide precisely because Uyghurs were a minority (Dillon 25). The mass migration has also been interpreted by Uyghurs as a strategy for Chinese assimilation ${ }^{1}$. The tremendous influx of Chinese immigrants since the 90s has become a primary source of tension between Uyghurs and the Chinese. Historically, the Chinese have used migration policies as a means of strengthening Chinese control in minority areas, and today the central government is adhering to a similar strategy in attempting to enhance Chinese support by diluting local culture (Dillon 75).

\section{An Old Revolution}

Over the years, the word "revolution” has developed an ambiguous albeit prestigious meaning in popular language. Revolution has been variously defined in terms of the form a struggle may take, such as through violent upheaval, or in terms of its objectives, such as a radical shift in political or social thought. Slavoj Zizek in "Revolutionary Terror” writes that the notion of what form of revolution had become so entrenched in violence that in order to regain political efficacy, revolutionary terror had to be divorced from the revolution: “...everyone, the contemporary 'radical left' included, is

\footnotetext{
${ }^{1}$ When Xinjiang was designated as an autonomous region in 1955, the population was composed of only five million people, in which the Uighurs constituted $75 \%$ of the population and Han Chinese accounted for five percent. Today, Uighurs constitute $45 \%$ of the population according to the most recent Chinese census (Becquelin).
} 
somehow ashamed of the Jacobin legacy of revolutionary terror with its state-centralized character, so that the current doxa is that the Left, if it is to regain political efficacy, should thoroughly reinvent itself, finally abandoning the so-called 'Jacobin paradigm’” (158-159). Zizek implies that revolution should "reinvent" itself by emphasizing not its form, which was the legacy of revolutionary terror, but instead focus on its actual agenda for transforming political systems of power. Ensuring the continuing political salience of a revolution relies then not on the threat of violence, but on its capacity for reinvention.

In illustrating how human rights reinvent nationalist revolution, it is important to first trace how nationalism and human rights are deployed similarly as both a rhetoric and means of resistance. For instance, nationalism, like human rights, is always invoked retroactively. In other words, both human rights and nationalism are invoked the moment after a violation has occurred. They become a corrective means for resolving injustice against the "imagined communities" (Anderson) of the nation and humankind. Human rights discourse then, operates on a similar model as nationalism. In human rights discourse, there is a parallel imagining of a universal human community which "is always conceived as a deep, horizontal comradeship" that nevertheless "will never know most of their fellow members, meet them, or even hear of them” (Anderson 7). In this sense, an emerging new nationalism, one which has not yet become formally decolonized, will always invoke the rhetoric of human rights as immanent within nationalist articulations of freedom and liberty. The basic tenets of the French Revolution and of subsequent ones life, equality and fraternity - are the basic principles of the United Declaration of Human Rights. Article 1 states, “All human beings are born free and equal in dignity and rights. They are endowed with reason and conscience and should act towards one another in a spirit of brotherhood” (United Declaration of Human Rights Article 1). 


\section{Agency and Representation in Memory Making}

In 2009, Dragon Fighter was published in an English edition ${ }^{2}$. Kadeer begins her memoir with a genealogy. She narrates the revolutionary life of her grandparents, telling the time when her grandfather set fire to a Manchu palace, of resisting Chinese armies (Kadeer 7). By beginning with this genealogy, Kadeer posits that revolutionary spirit runs in her blood, implying that it was destined that she would attempt to revolutionize the Uyghur nation. In the first few pages, Kadeer says, "For as long as I can remember, Uyghur people have been tortured and subjugated by foreign powers... I come from a land that has been fighting for its independence and freedom for a long time - today more than ever before...I speak and fight for approximately twenty million Uyghurs worldwide” (Kadeer 4). Kadeer positions herself not only as a metonym for the broader experiences of the Uyghur people, but as the catalyst in refiguring Uyghur subjection to Chinese colonialism. She situates herself as the only person who is able to "speak and fight" on behalf of twenty million people by depicting herself as an exception to the Uyghur experience. In offering her own memoir as an example of Uyghur consciousness, Kadeer becomes both the exception and standard of the Uyghur experience, and it is precisely her exceptionalism which authorizes her to use her own particular memory as the basic narrative arc of Uyghur collective memory. Kadeer attempts to occupy both positions simultaneously: that of a universal Uyghur consciousness, and also the particular exception of her own life as humble housewife, millionaire, representative in the National People’s Congress of China, political prisoner, founder of the ultimately disbanded Thousand Mothers group in Xinjiang, exiled political dissident, and now human rights activist.

\footnotetext{
${ }^{2}$ Random House originally published the book in German in 2007.
} 
Testimonial literature such as Kadeer’s, although attempting to create solidarity and awareness around a cause or group, must necessarily obscure collective consciousness in order to authorize the autobiographical "I" as truly representative. This tension of moving from the autobiographical "I” to collective Uyghur consciousness produces several effects: first, in representing herself as a character, Kadeer gives up all rights to interpretations of her life as text in order to authorize the development of the reader's. Secondly, the autobiographical “I” of Kadeer’s memoir must follow the narrative arc of beginning, middle and end. All literature must have an ending, but this demand can also lend to a false sense of completion or conclusion, as the reality is that there is yet no conclusion or foreseeable end to Kadeer’s story. In eliciting sympathy for Kadeer and her cause, the full experience of Uyghur consciousness and experience is ironically reduced to the experiences of an exceptional, single individual.

\section{Gendering Resistance}

In moving towards a revolutionary consciousness, Kadeer sees herself as an agent of change and transformation in her ability to refigure scenes of subjection. Perhaps the best example of this is her endeavor to convert what was a "garbage dump” into a bazaar (Kadeer 179). The dump, an old square filled with old plastic, glass, wood and burned garbage, had been abandoned due to its "bourgeoisie” label during the Cultural Revolution. As the only one who is not only able to identify but also envision new possibilities for this space, Kadeer sets herself apart from the unenlightened masses, particularly her male colleagues. Since the space was owned by the Chinese government, re-imagining the square as an expansion of feminine space can be interpreted as a reclamation project on several levels - first, as an extension of feminine space and economic autonomy outside the 
home, and secondly, as a partial reclamation of the Uyghur motherland from Chinese forces.

Nationalism, as pointed out by many writers, is constantly preoccupied with its ties to an origin distinct from others. In connecting women to the formation of nationalism then, women become integral to conceptions of nationalism since after all, where do all people come from except from women? If women can be interpreted as a multiplicity of origins themselves, then the reproduction of nationalism can be compared to a perpetual rebirth as nationalism itself is constantly reborn according to current political demands. As a great deal of literature has shown, the feminine body is easily appropriated for nationalist projects. As a symbol of the traditional, or as I suggest, an origin, the female body comes to additionally symbolize a futurity. In other words, the female body within nationalist discourse signifies the reproduction of a common origin and the production of a common destiny. Kadeer utilizes this trope in an attempt to relocate feminine agency throughout her memoir. However, although Kadeer does not wish to situate women as the passive body of the motherland, she nonetheless reduces women to their bodies in relegating the role of women to the formation and transmission of nationalism.

\section{Revolution and Human Rights}

To achieve emancipation, Kadeer uses human rights as the primary grounds for instigating a radical shift in power within Xinjiang. However, at the end of her memoir, it remains unclear as to what Kadeer actually wants. Does she want a free Uyghur nation? Or is she content for a radical revision of existing power structures as long as oppression and inequalities are alleviated within Xinjiang? Although she situates human rights as the prime rationale for launching a Uyghur revolution, the failure to specify her desire and instead 
stress human rights only serves to reinforce how human rights itself can be used as an analytical and political cop out. The narratives implicit within human rights and revolution involve both "good" and "bad" characters, and both operate on an oppressor/oppressed binary. In other words, human rights work inherently situates itself as the positive to the negative - because after all, how can one be against human rights? Within this logic, the reader is compelled to remain on the "good" side of human rights (and Kadeer) even though an explication of how those rights are to be politically expressed remains unclear. She intensifies the binary by demanding that "the Chinese government [be] brought in front of an international human rights tribunal for its criminal suppression of the Uyghur population” (Kadeer 390).

Interestingly, Kadeer merely states that her goals are simply for human rights: "For my countrymen, I wish for basic human rights. That is our goal. The rest will develop outwardly from respect for human rights” (Kadeer 390). Kadeer does not call for outright separatism in her memoir, nor in interviews. Instead, she believes that the "rest will develop outwardly from respect for human rights." The ambiguity of the "rest" is particularly charged since China has accused Uyghurs of "threatening social stability" and “separatist movements” (Information Office of the State Council). Situating human rights as a (presumably) apolitical platform for transformation can be used to evade potentially serious political conflicts. In this sense, it is likely that Kadeer is deliberately ambiguous about the desire for a Uyghur nation due to fears of increased retaliation of the Chinese within Xinjiang. However, her belief that the "rest will develop outwardly from human rights:, implies that human rights are central in invoking any movement for radical change. By situating revolution as consistent with human rights, an important question arises: if the goal of the revolution is to induce radical change in the state, and if the state 
accepts the terms of the revolution, does this then indicate that the revolution has been coopted and thus neutralized by the state? If a revolutionary victory yields a radical transformation within existing political and social structures of hegemony through the act of the state agreeing and participating in the revolution, then it would seem that though the revolution is being assimilated, it can nonetheless be considered a victory. However, I would argue that it is not the state assimilating the revolution, but that it is the revolution assimilating the state in actualizing its demands. Co-opting the state in the revolutionary agenda is thus a means for the revolution to negate itself; revolution fundamentally strives for its own negation. Zizek discusses the revolution as a "negation of the negation”. He writes:

The true victory (the true "negation of the negation") occurs when the enemy talks your language. In this sense, a true victory is a victory in defeat: it occurs when one's specific message is accepted as a universal framework, even by the enemy... (189)

A successful revolution can thus be characterized as one in which the enemy, or state, internalizes the goals of the revolution as its own. The victory is the moment the revolution is no longer needed since the radical change is being produced by the state itself. To universalize, or win the revolution, therefore, is to export it to a completely foreign context. In the case of a revolution of human rights, that foreign context is the state. Zizek goes on to insist that the survival of an ideology or teaching is to transplant it into a variety contexts. In other words, an ideology can only be universalized if it is taken out of its original context and transplanted into a variety of new contexts; ideologies are made universal in its ongoing reinventions and re-contextualizations. The reinvention which Zizek refers to is not a complete transformation of the original idea, but an adaptation of it, and as such, an inexorable iteration of the “original”. Reinvention demands corruption of 
the "original" since any adaptation of it to another context becomes a fundamentally different iteration of the “original”. Applying Zizek’s analysis of the necessity of "betrayals" to the "original" offers a useful perspective in re-evaluating what the victory of revolution would resemble. If the "teaching" as Zizek referred to is made to correspond to the agenda of the revolution, "true victory is a victory in defeat". In this sense, the revolution is won when it assimilates the state into its movement and uses the state to universalize the political and social goals of the revolution.

Throughout this paper I have sketched a workable relationship between women, memory and nationalism in illustrating the possibilities of human rights propelling revolutionary movements and figures forward. As seen through the memoir of Rebiya Kadeer, the formation of nationalism is predicated on collective memory and the appropriation of female bodies to current political projects. Nationalism relegates the feminine body as both the reproducers of a collective memory and as the producers of shared future. Kadeer's movement from unenlightened individual to full fledged freedom fighter highlights not simply a resistance to patriarchal systems of authority, but also the failure of the state to recognize a feminine resistance as legitimately viable and threatening until she has achieved revolutionary momentum. Kadeer, in stressing the lack, if not impotence of masculine resistance to Chinese colonialism, re-positions women as the rightful agents of change. In actualizing a revolution for Uyghur freedom, she specifically omits a description of what that freedom involves in order to side step the contentious issue of separatism. However, her belief that "the rest will develop outwardly" from human rights itself implies that human rights by definition must demand revolutionary movements in catalyzing any transformation. Because of the failure of the state, Kadeer exploits human rights as the moral lingua franca as a means of rendering herself and her cause legible to 
transnational agencies in an effort to induce the state itself to change, and thus participate to her terms of revolutionary change. In understanding human rights as a reinvention of revolution, we can hope to re-imagine where all the revolutionaries have gone.

Works Cited

Amnesty International. China: Uyghur Ethnic Identity Under Threat in China, 2009.

December 12, 2009

<http://www.amnesty.org/en/library/info/ASA17/010/2009/en>.

Anderson, Benedict. Imagined Communities: Reflections on the Origin and Spread of Nationalism. Verso, 1983.

Becquelin, Nicolas. "Xinjiang in the Nineties." The China Journal 44 (2000).

Dillon, Michael. Xinjiang - China's Muslim Far Northwest. RoutledgeCurzon, 2004.

General Assembly of the United Nations. "The Universal Declaration of Human Rights."

United Nations. 1948. < $\underline{\text { http://www.un.org/en/documents/udhr/>. }}$

Gladney, Dru C. Dislocating China : Reflections on Muslims, Minorities, and Other

Subaltern Subjects. Chicago: Chicago : Univ. of Chicago Press, 2004.

Kadeer, Rebiya. Dragon Fighter: One Woman's Epic Struggle for Peace with China. Ed.

Alexandra Cavelius. New York: Kales Press, 2009.

Millward, James A. Eurasian Crossroads: A History of Xinjiang. Columbia University

Press, 2007.

Slaughter, Joseph R. "Enabling Fictions and Novel Subjects: The Bildungsroman and International Human Rights Law." The Modern Language Association of America 121.5 (2006): 1405.

Zizek, Slavoj. In Defense of Lost Causes. New York: Verso, 2009. 